\title{
CONFUCIAN ETHICS AND LABOR RIGHTS
}

\author{
Business Ethics Quarterly 24(4), 2014; 565-594
}

Tae Wan Kim

Carnegie Mellon University

\begin{abstract}
In this article I inquire into Confucian ethics from a non-ideal stance investigating the complex interaction between Confucian ideals and the reality of the modern workplace. I contend that even Confucian workers who regularly engage in social rites at the workplace have an internal, Confucian reason to appreciate the value of rights at the workplace. I explain, from a Confucian non-ideal perspective, why I disagree with the presumptuous idea that labor (or workplace) rights are necessarily incompatible with Confucian ideals and values. Specifically, I argue that if managers were "sages," the highest moral exemplars and authorities in the Confucian tradition, they would perceive that social rituals alone are often not a contextually intelligent and valued response for the development of intimate communities in the modern workplace. The sage perspective will lead Confucian managers to realize, from their own moral perspective, that they have good reason to balance rites with rights, so long as the adoption is extrinsically valuable and consistent with the Confucian ideal. This article contributes to the debates about Confucianism's compatibility with rights, helps Western human rights scholars better contextualize their arguments in Confucianism-influenced cultures, and contributes to the development of a Confucian or Chinese approach to business ethics.
\end{abstract}

Keywords: labor rights, Confucianism, sagehood, non-ideal theory, community, Chinese business ethics.

\section{INTRODUCTION}

As Daniel Bell (2008: 76) says, "a basic assumption of Confucian ethics is that the moral life is possible only in particularistic personal ties," by which he refers to family-like or community- 
like ${ }^{1}$ intimate relationships. ${ }^{2}$ This feature of the Confucian good life has drawn varied scholars into prolific debates over the relation between the Confucian moral life and rights, especially human rights (e.g., Ames 1988; Angle 2002, 2012; Chan 2014; de Bary 1998; R. Fan 2010). ${ }^{3}$ Since rights are often regarded as "conflict notions" which undermine intimate communities - as noted by both eastern and western scholars (Sandel 1981; Taylor 1985; Tiwald 2011; Williams 1981) —individuals like Henry Rosemont Jr. $(1988,1991,2004,2008)$ have maintained that Confucianism is incompatible with treating people as "rights-bearers," or those who can invoke rights against others, likely making their relationship adversarial. ${ }^{4}$ Instead, Rosemont (1988,

I acknowledge comments from Stephen Angle, Alan Strudler, and audience members (especially, Miguel Alzola, Gaston de los Reyes, Michael Kates, Phil Nichols, and Amy Sepinwall) at the Carol and Lawrence Zicklin Center for Normative Business Ethics Works-in-Progress series on earlier drafts of this article. Three anonymous reviewers provided excellent guidance. Especially, I acknowledge a great debt to Editor-in-Chief Denis Arnold.

${ }^{1}$ Although I recognize that there are differences between the two, I shall use the terms "familylike" and "community-like" as almost synonymous. For Confucians, the non-familial is in continuum with the familial (Kim 2010) and in Confucianism-influenced East Asian countries what is meant by the term "family" is often extensive enough to cover what Westerners mean by "community."

${ }^{2}$ Of course, Confucians do not believe that the Confucian moral life is constituted exclusively by specific roles of intimate community (see Chan 2004). Still, no serious Confucian would deny that the role-bearing person is the most crucial component of the Confucian good life.

${ }^{3}$ According to Angle's (2012: 81) typology, there can be five different Confucian positions with respect to rights. "1. Confucianism has recognized human rights from the beginning. Confucians (and a hypothetical modern Confucian polity) have no difficulty endorsing human rights today. 2. Confucianism is incompatible with human rights, and should reject them today as parochial and problematic. 3. Confucianism did not historically develop a doctrine of human rights, but it is compatible with such an idea, and can endorse it today. 4. Confucianism did not historically develop a doctrine of human rights, but in order to realize its own core commitments, it is necessary that it now develop the resources to do so. 5. Confucianism did not historically develop a doctrine of human rights; it is necessary that it now develops the resources to do so, and the result will be transforming Confucianism into Western liberalism. Confucianism as a distinct philosophical position will cease to exist." Angle (2012) defends a version of 4, drawing upon the contemporary scholar, Mou Zongsan's political philosophy. In this article, I will also defend a version of 4, by drawing upon a more classical Confucian idea.

${ }^{4}$ Consider, for instance, "a faithful husband of thirty-seven years" who "were, on his deathbed, to turn to his wife and say, "My conscience is clear, Helen, I have always respected your rights" (Hardwig 1984: 443). As John Hardwig (1984: 443) points out, "her whole marriage would turn 
1991, 2004, 2008), for instance, argued that Confucian ethics is most consistent with treating people as "rites-bearers," or those who observe social rituals, rites or ceremonies ${ }^{5}$ together and in so doing cultivate family-like intimate and affective ties, by virtue of which they have certain role-specific obligations to each other. A parallel argument could reasonably be applied to the workplace, that while workplace rights are incompatible with the Confucian moral life, workplace rituals, if properly observed, can serve as a workable alternative, so that while rights should not be allowed at the workplace, social ritualization must be extensively facilitated for the cultivation of intimate communities at the workplace. In this article, I contend that even Confucian workers who regularly engage in social rites at the workplace have an internal, Confucian reason to appreciate the value of labor rights.

Arguments such as Rosemont's $(1988,1991,2004,2008)$ have some truth. I also find Confucianism, as an ideal and an aspirational normative theory, to be useful in theorizing about how one ought to ideally live a good life. Note, however, that we must accept the cold fact that the modern workplace is a mostly non-ideal condition for the Confucian good life, as I shall explain later in more detail. Of course, social rituals work, but not always faithfully, dependably, or consistently; realistically, they have vulnerabilities and limitations, and, even if successfully felicitous, often take considerable time in actual settings. Undoubtedly, it must be emphasized that Confucians must keep in mind the significance of ritual and the aspiration it manifests about how to piecemeal or even fundamentally restructure background business institutions and ethos, so as to transform them into places where the Confucian, harmonious, intimate community can

to ashes." See, also, Bernard Williams's (1981) discussion about "one-thought-too-many"-a misplaced rationale or motivating thought that moral agents would have when they claimed rights to intimates.

${ }^{5}$ For present purposes, I shall use the terms, "rite," "ritual," and "ceremony" as almost synonymous. 
ideally flourish. Nonetheless, this type of long-range planning towards an intimate Confucian community would not be a linear path. Therefore, those who worry about the moral life of Confucian workers should realize that they have a more pressing problem here and now. In response to this urgent issue, in what follows I shall develop a Confucian non-ideal perspective, ${ }^{6}$ explaining why I disagree with the presumptive idea that workplace rights are necessarily incompatible with Confucian ideals and values. I shall attempt to show how the notion of workplace rights, obviously of western origin, ${ }^{7}$ once adapted to the needs of Confucianism, can be extrinsically required to promote the Confucian ideal of particularistic ties, which would make the Confucian view distinct from the western liberal view of rights.

In Section 2, I introduce a practical problem that western human rights activists or business people face in Confucianism-influenced cultures and preview my solution to the problem. In Section 3, an existing solution is critically examined. In Section 4, I develop a nonideal Confucian perspective. In Section 5, this non-ideal Confucian perspective is applied to contemporary Chinese workplaces, and I explain how workplace rights are compatible with the Confucian good life. In Section 6, I conclude by replying to possible objections.

\section{THE PROBLEM}

I find it more effective to introduce the problem at hand, and my approach to it, through a practical example. So I begin with a variant of Alan Strudler's (2008: 68) imagined, but highly probable, story about Confucianism and its relation to workplace rights:

\footnotetext{
${ }^{6}$ See, Chan (2014) for a Confucian non-ideal political theory.

${ }^{7}$ For an argument supposing that there is already a concept of rights in the Confucian classics, see Lee (1992).
} 


\section{JAYNE'S STORY}

Suppose that you, Jayne, are an active member of an international non-profit organization with a mission to promote the institutionalization of human rights protection in China. ${ }^{8}$ You have been much influenced by human rights-based perspectives (Arnold 2013; Bishop 2012; Campbell 2006; Cragg 2012; Goldman 2005, 2007; Mulchlinski 2012; O’Brian \& Lianjiang 2006; Santoro 2000, 2009; Wettstein 2012; Wood 2012) that infuse much of the Western literature on contemporary China. ${ }^{9}$ In particular, you are concerned about the precarious working conditions of a certain mobile phone manufacturer in a rural area of Southern China—conditions that include minimum wage violations, compulsory overtime, shifts of up to 16 hours, lack of breaks and vacation days, and opaque grievance procedures. ${ }^{10}$ For the last two years, you have attempted to persuade the Chinese plant manager and local officials to institutionally acknowledge relevant

\footnotetext{
${ }^{8}$ For more detailed information regarding international NGOs' challenge of cultural and political conflicts in China, see Bell (2006: Ch. 4) and Shieh (2009). For an historical description and assessment of international NGOs' roles in a human rights dialogue between the EU and China, see Kinzelbach and Thelle (2011). For a critical assessment about capabilities that international NGOs can have in China, see Ivan (2014).

${ }^{9}$ Elizabeth Perry $(2007,2008,2009)$ at Harvard-Yenching Institute recently questions the "rightbased challenge" perspectives, criticizing those (e.g., O’Brian \& Lianjiang 2006; Goldman 2005, 2007) who explain popular protests in China through "an Anglo American language of human rights" (Perry 2008: 37). Perry claims that "rights consciousness" is not an appropriate explanation but that a much older and culturally familiar "rules consciousness" better captures Chinese workers' attitudes. As I shall explain, culturally familiar "rules consciousness" can sometimes be expressed in terms of "rights consciousness" and even sometimes "rights consciousness" is necessary to express "rules consciousness." Therefore, the question is not which one is correct between the two. The real question is how the two types of consciousness can appropriately be related to each other.

${ }^{10}$ According to a recent study (Wong 2011), in cases of Chinese migrant workers, $46.9 \%$ did not sign a labor contract, only $29.1 \%$ joined the work injury scheme, and $15.3 \%$ of workplaces have arbitrary scolding and beating. For philosophical discussions about moral issues in "sweatshops" in developing countries, see Arnold and Bowie (2003, 2007) and Snyder (2010).
} 
labor rights (e.g., a right to be paid lawful wages, a right to organize, a right not to be forced to work overtime, a right not to be unfairly discriminated against) and allow the workers to act on them. The manager and officials have furiously refused your proposal with a moral argument: they claim that because much of the rural area's cultural structures are founded on Confucianism, allowing workers to act on rights, which would undercut family-like intimate communities at the workplace, would potentially undermine traditional cultural structures (Peerenboom 1998). ${ }^{11}$ Furthermore, the manager and officials have told you that all members of the plant regularly observe various workplace social rituals such as retirement rituals, corporate anniversaries, seasonal events, and recognition ceremonies (see Deal and Key 1998; Smith and Stewart 2011), the moral significance of which almost all versions of Confucianism since ancient times have incontestably emphasized (see e.g., Angle 2012; Ames 1988; Eno 1990; Fingarette 1972; Kim and Strudler 2012; Kupperman 2010; Olberding 2009; Shun 1993; Solomon, Lo and Fan 2012; Woodruff 2001). Having repeatedly heard the manager and officials' moral argument, you are quite at a loss about what to say. ${ }^{12}$

${ }^{11}$ Since Peerenboom (1993: 32) testified a decade ago, "Confucianism continues even today to be the basis of the Chinese world view, despite the attempts of the socialist government to eradicate such "feudal thinking," more signals have been observed about the resurgence of Confucianism in contemporary Chinese society. For instance, there are schools that developed curricula based on the Confucian tradition, including weekend classes in memorizing and chanting Confucian classics; popular television shows expounding the lessons of Confucianism; Professor Yu-Dan's best-selling book, Yu Dan's Insights Gleaned from the Analects; Confucianism's central role in the Opening Ceremonies of the 2008 Beijing Olympic Games. For more detailed information, see Angle (2012: Ch. 1) and newspaper articles collected in Joy Y. Lam's blog, "Revival of Confucianism in China" (http://revivalofconfucianisminchina.blogspot.com).

${ }^{12}$ Of course, this is a hypothetical, but similar arguments could reasonably be made in China. For instance, in 2008, the State-Owned Assets Supervision and Administration Commission of the 
In what follows, I attempt to help Jayne, the human rights activist, or those in similar real world situations ${ }^{13}$ persuade the Chinese manager and local officials to implement workplace rights, ${ }^{14}$ while at the same time helping the Chinese workers preserve their Confucian moral identity. Two different argumentative strategies might rationally persuade the plant manager and governmental officials. One is to argue that Confucianism itself is a corrupt ideology; therefore, the moral argument, based upon a corrupt idea, is a bad argument. This radical path, though theoretically imaginable, is not one I shall undertake in this article. The other strategy, which seems more ad rem, is to argue — acknowledging that Confucianism could be a workable theory to introduce Chinese workers to a plausible version of the good workplace life - that the Confucian moral life could demand one to practice rights in Confucian ways as well as observe rites under certain circumstances in the modern workplace. I will advance this second path. I will

State Council (SASAC) released an important governmental document called "The Guide Opinion on the Social Responsibility Implementation" for state-owned business enterprises. Although the document shows the Chinese government's progressive movement toward promoting socially responsible business in China, it does not include human rights protection in its explanation of what constitutes responsible business (Lin 2010). To the question why, a government official's response in a Q\&A session was that "the Guide Opinion" must be consistent with international standards but also compatible with "the national and organizational reality in China" (Lin 2010: 74). The official's term, "the national and organizational reality," could solely mean the economic reality, but it could also include the cultural reality, including Confucian heritage and customs.

${ }^{13}$ My argument can have implications for Western corporations that want to positively influence labor conditions in China (see, e.g., Santoro 2000, 2009). Attempts to influence Chinese society through the western language of human rights can make the Chinese see the attempts as undermining their own moral identity. Explaining why human rights are important from their own perspectives, which would not undermine their moral identity, can better persuade them. In this article, I take such a path.

${ }^{14}$ The manager and officials might simply be hypocrites who do not care about the Confucian moral identity at all. Then, any reasoned argument would not rationally persuade them. I do not believe that all Chinese managers and officials are simply hypocrites. Many of them I have met were sincerely worried about their cultural and ethical heritage. Even in cases of hypocrites, a reasoned argument can at least make it so that they no longer hide behind Confucianism. 
specifically draw from and expand upon influential Contemporary Confucian scholar Stephen Angle's recent book, Sagehood (2009) to establish that if the Chinese managers and officials were "sages" (聖人: shengren), the highest moral exemplars and authorities in the Confucian tradition, they would perceive that social rituals alone are not often a contextually intelligent and valued response for the development of family-like affective, intimate communities in the modern workplace. The sage perspective will lead the local officials and manager to realize, from their own cultural perspective, that they have good reason to balance rites with rights in contemporary workplaces, so long as the adoption is extrinsically valuable and consistent with the Confucian ideal. In the end, Jayne, the western human rights activist, will be encouraged to make to the manager and officials a proposal based on a different way - a more contextualized way — of thinking about the value of workplace rights.

Since the primary concern of this article is the moral life of workers in countries with Confucian heritage and customs such as China, Singapore, Taiwan, Vietnam, Korea, and Japan, the argument primarily targets specific types of readers-Confucians, and those interested in Confucian ethics. The Confucian argument I will develop in this article, therefore, might not be perfectly persuasive to those who believe that the good life need not necessarily exist in an intimate community or that one can surely live a good life even though one's workplace life is solitary and lonely. Nonetheless, I hope that the Confucian argument is persuasive to those who, like Confucians, consider intimate communities to be fundamentally important for living the good life (for instance, western communitarians and virtue theorists) and to those who believe that the workplace life is a crucial, irreplaceable component of our lives (most western business ethicists). 


\section{CONFUCIAN WORKERS AT A CROSSROADS}

Let me first discuss an existing answer to Jayne's problem, which I believe is not yet compelling to the plant manager and officials. Not long ago, Strudler (2008) argued that even Confucians, who see themselves as endorsing a distinctive way of life incompatible with regarding themselves as rights-bearers, must admit the value of rights at the workplace and accept that doing so would not defuse the moral life of Confucian workers. Strudler first agrees with Craig Ihara's (2004) basketball team analogy, in which team members (the center, the guard, the forward, etc.) have role obligations they must harmoniously fulfill to achieve a shared goal, but do not have individual rights to each other. The analogy shows, Ihara (2004) claims, that the liberal rights theorist Joel Feinberg's $(1970,1973,1980,1992)$ defense of the dignitary value of individual rights ${ }^{15}$ is not necessarily valid in basketball-team-like, role-dependent harmonious communities such as families or clan societies - practices or relationships in which nearly all members mutually share the common good, which in turn prescribes each member's role-dependent obligations. In a family, for instance, when an older brother gratuitously offends his younger brother, the offensive act can be properly addressed as an ethical failure by defining it as a failure of the offender's role-dependent obligation. The younger brother could say, for

${ }^{15}$ In this section, following Ihara (2004) and Strudler (2008), I focus mainly on Feinberg's $(1970,1973,1980,1992)$ account of rights. No doubt, other competing accounts exist (e.g., Dworkin 1984; Nozick 1974, Thomson 1990). Yet, most of the differences in those accounts lay in justificatory processes, while the problem at issue in this article mainly lies in the results of claimed-rights upon the community. Hence, considering other accounts would not necessarily make substantial differences to our discussion. Notably, however, Alan Gewirth's (1996) account might have a substantial difference, because Gewirth (1996: 81) argued, "The society based on the PGC [Principle of Generic Consistency] as the principle of human rights, with its mutualist sharing of rights and duties is a genuine community." Hence, for Gewirth, there should not be a conceptual conflict between rights and community from the beginning. But there seem to be differences between Gewirth's community and the Confucian ideal community mirroring well-functioning family. Gewirth's community seems more like associations of fellow citizens who do not necessarily possess a family-like intimate relationship. 
instance, "That's not what an older brother is supposed to do to his younger brother"-and doing so would not involve any appeals to the vocabularies or incidents of rights such as claims, duties, powers or privileges (to use the Hohfeldian analysis system ${ }^{16}$ ). If the younger brother invoked a claim-right not to be offended against his older brother, asking him to respect the correlative- $\mathrm{a}$ negative duty not to offend him—by virtue of the fact that they are fellow human beings or citizens, rather than by virtue of the fact that they are family members, his request would be presumptuous and, as Tiwald (2012) points out, could potentially make the family seriously dysfunctional. In this article, for simplicity's sake, let us term such a basketball-team-like, roledependent harmonious communities the "Confucian ideal condition."17

Nonetheless, Strudler correctly pointed out that most typical, modern workplaces, in which adversarial conflicts between employees and employers, and also among employees, are frequent and perhaps non-eliminable, are not like the Confucian ideal condition. ${ }^{18}$ Since the Confucian's communal/familial way of addressing wrong, which need not involve any incidents

\footnotetext{
${ }^{16}$ For a detailed analysis of the Hohfeldian framework and how current debates about human rights can be understood through the framework, see Arnold, Audi and Zwolinski (2010: 572574).

${ }^{17}$ The distinction between ideal and non-ideal theory and conditions was first coined by John Rawls (1971: 7-9) to describe the kind of theory of justice he was seeking (see also Phillips 1985; Simmons 2010). As various recent review articles commonly indicate (Hamlin and Stemplowska 2012; Stemplowska and Swift 2012; Valentini 2012), literature regarding the distinction between ideal and non-ideal theory has used the terms in incommensurably different ways. Hence, it is complex to figure out what ideal or non-ideal conditions consistently mean in Western literature. Furthermore, the discussion is primarily focused on the political domain. So, I find it difficult to directly apply either Rawls's or any other recent western conceptualizations of distinction to our business context. In our context, ideal theory or perspective simply stands for an account designed under the following condition, which Ihara (2004) and Strudler (2008) specified: nearly all relevant agents share the common good that prescribes communal norms and each member's role obligations. Confucian non-ideal theory or perspective corresponds to the negation of the condition.

${ }^{18}$ In fact, more communal management practices associated with clan-like relationships, interpersonal trust and mutual commitment have fallen by the wayside in most organizations, at least in the U.S., and the organizations have moved to more market-like, distinct, transactional and impersonal mechanisms such as prices and contracts. See, for example, Pfeffer (2006).
} 
of rights, can properly function only in contexts similar to the Confucian ideal condition, Strudler claimed that the Confucian's role-dependent approach to addressing wrong would be inadequate in the conflict-ridden workplace - a non-ideal condition to Confucians. To see this, simply suppose that a worker, Yang, insists when her supervisor, Liang, humiliates her, ${ }^{19}$ that the supervisor has failed to fulfill a role-dependent obligation, saying, "It is not what a higherranking individual is supposed to do to a lower-ranking individual!" The manager could easily deny the role-dependent communal charge by rebutting that the role-dependent norm does not have any relevance, because no harmonious community holds both of them; instead, they are in a conflict-ridden relationship. The worker, Yang, then becomes a helpless victim who cannot hold the manager, Liang, accountable for the harm.

Because this lack of blame attribution is absurd, and this absurdity could be avoided if rights were endorsed at Yang's workplace, Strudler (2008: 76-77) submitted that since "it is necessary, as a matter of principle, to accord people the highest kind of dignity available ... in the absence of community, the dignity in rights regains its luster, and Feinberg's arguments for rights become again powerful." Thus, "in the peculiar context of the workplace," Strudler concluded, "even a Confucian must admit that doing so requires recognizing rights." Interestingly, according to Strudler, Yang and Liang's endorsement of rights at the workplace would not be incompatible with Confucianism, because the modern workplace does not reside inside the legitimate scope of Confucian moral discourse - that is, the Confucian ideal condition, like Rawls's principles of justice, does not apply to any concepts other than basic structures of society (Rawls 1971: sect. 2).

${ }^{19}$ For a further discussion about humiliation, human rights and dignity, see Kim (2014: 211214), Lindner (2001), Luban (2009), Margalit (1998). 
I claim that Strudler's argument may be valid but not yet compelling to someone like the Confucian manager and the local officials in the above hypothetical. It is not yet compelling because one could construe Strudler's argument to mean that Confucian workers should give up being Confucian in non-ideal conditions like the modern workplace, although they could maintain their distinctive Confucian identity in the Confucian ideal condition like family, friendship or clan. It is true that individuals like Jiwei Ci (1999) have argued that Confucianism is inadequate outside the family and intimate communities. $\mathrm{Ci}$ (1999: 334) remarks:

"[T]hey [Confucians] do not know how to relate to others except on the basis of family and kinship ties. [...] As a result, those who have absorbed the Confucian concept of human relations would be socially and ethically at sea if they were to enter into relations with strangers $[\ldots] . "$

Granted, one might further construe Strudler's argument to suggest that Confucian workers have good reason to turn into Feinberg-type liberals - those who rely on individual rights to solve conflicts - at the workplace, given that liberalism in general is a workable alternative particularly well positioned to governing non-familial or more Hobbesian interactions. In what follows, I shall disagree with both Strudler and Ci.

Would, then, the argument that adjures Confucian workers to give up their traditional moral identities at the workplace be compelling and persuasive to the Confucian plant manager and officials? I am skeptical. Note that they have refused to admit rights at the workplace mainly because they did not want to see the distinctive Confucian life tainted by a rights regime. Their argument, if syllogistically restructured, would be that: i) Rights undercut the distinctive 
Confucian life; ii) The workplace where Chinese workers regularly observe social rituals is an important site for the Confucian life; iii) therefore, rights must not be permitted at the workplace. As premise ii) shows, the Chinese manager and officials' moral argument supposes that the Confucian life must be fully realized in public spaces like the workplace. In fact, this concern is highly consistent with historical and contemporary Confucians' serious efforts to accomplish full Confucian virtue in the public domain, for instance, in politics (e.g., Angle 2012; Bell and Chaibong 2003; Chaihark and Bell 2004), medicine (e.g., Fan 1999), and business (e.g., Cheng 1992; Koehn 2001).

At this juncture, one might ask: Why wouldn't Confucians acquiesce to being liberals at the workplace? Why not live with two moral identities? There are at least two simple but convincing reasons, I believe. First, workers spend the majority of their waking hours working. Given the reality that working life is an inseparable part of contemporary life (Schor 1992), people who strive to embody a certain lifestyle — whether it is liberal, egalitarian, Quaker, or Confucian — have good reason to pursue it at the workplace as well as at home. ${ }^{20} \mathrm{~A}$ second, related but more profound reason is that a life with moral integrity is better than a schizophrenic moral life. The life in which a person can consistently maintain the self she believes she ought to be seems objectively healthier than the life in which a person sporadically gives up the self in the face of unconducive conditions. ${ }^{21}$ Hence, an argument that provides the manager and officials with reasons to admit the value of rights while at the same time preserving the Confucian

\footnotetext{
${ }^{20}$ In addition, as an empirical matter, working life can have spillover effects that make the domain of family similar to the domain of work (Edwards and Rothbard 2000; Grzywacz and Marks 2000; Ilies, Wilson, and Wagner 2009).

${ }^{21}$ I realize that my claim that a life with integrity is better than one without is a topic that requires deeper philosophical discussion. Such an exploration, unfortunately, would be a distraction in this article. In this article, I assume that the life with integrity is better than the one without. For more detail analysis of why the life with integrity is important, see e.g., Tessman (2005: Ch. 1).
} 
worker's moral identity at the workplace would be much more compelling to them. In what follows, I will attempt such a task.

To successfully make this claim, two conditions must be met. First, the rationale must be genuinely Confucian. Confucianism comprises varied perspectives and interpretations, so disagreements exist about the details, even within the Confucian tradition itself. Nonetheless, the principle must be derived from the most widely accepted Confucian texts, ideals and interpretations. I expect that the first condition can be well satisfied by my exploration of sagehood. Second, the rationale must be a good explanation. The mere fact that a certain classical Confucian text contains an esoteric passage saying that Confucius, Mencius or Xunzi sometimes perceive that ritual is not enough and thus endorse something we now call rights does not by itself help the Confucian manager and officials realize how their workers could endorse the value of workplace rights while at the same time preserving their Confucian identities. Any adequate Confucian endorsement of workplace rights must be derived from a cogent account of the circumstances under which rituals are not enough and an explanation of the ways that rituals balanced with rights could help workers realize the fundamental ideals of Confucianism. I expect that the second condition can be satisfied by my exploration of how rights can be helpful to improve intimate communities in non-ideal conditions.

\section{SAGES' MORAL METAPHYSICS}

In this section, I provide the theoretical structure for a non-ideal Confucian stance, by which I can move forward to a specific non-ideal context - the modern workplace. Angle's book Sagehood (2009), in which he articulates Confucians' ongoing commitment to moral growth 
with an emphasis on concern for the given contextual condition, ${ }^{22}$ is useful in theorizing a nonideal Confucian outlook. ${ }^{23}$ Sages are exceptional humans, the highest moral exemplars and authorities in the Confucian tradition (Angle 2009). In the Aristotelian tradition, an act or attitude is good, right, mandatory or desirable to the extent that it is what a virtuous agent, the moral exemplar in that tradition, would do in the circumstances (see e.g., Hursthouse 2003); similarly, it can be said that an act, attitude or character-cultivation is good, right, obligatory or desirable for Confucians to the extent that it is what a sage would do in the circumstances. Therefore, if a sage would endorse some form of rights in addition to rites at the workplace, then it would be a strong Confucian internal argument to persuade those who are antagonistic to workplace rights because of their affinity to Confucianism.

Angle (2009:15) submits that Confucian sagehood represents "the human achievement of moral perfection." Moreover, he clarifies, "situational flexibility that enables one to bring out the best in a situation $[\ldots]$ is a hallmark of sagehood"(16). To understand why situational flexibility is weighty for sagely perfection, we need to decipher sages' moral metaphysics. According to Angle's elucidation, moral perfection for the Confucian sage is realized, when he (和) is fully

\footnotetext{
${ }^{22}$ Angle also shows, through a meticulous survey of various important versions of Confucianism, that almost all versions of Confucianism embrace the utmost significance of sagehood. Angle's textual survey includes Classical Confucians such as Confucius, Mencius and Xunzi, Neo-Confucians such as Zhu Xi and Wang Yangming, and Contemporary Confucians such as Mou Zongsan and Fuguan Xu.

${ }^{23}$ I will not be arguing for the truth of Angle's interpretation of various versions of the Confucian tradition. Such an ambitious question is beyond the scope of this article. The aim of this article is, assuming the validity of his works, to see how his interpretation is particularly useful to illuminating issues of workplace rights. For more detailed discussions about the debates, e.g., what Zhu Xi and Wang Yangming and other ancient and Neo-Confucians said about sagehood, how their perspectives differ from each other, and whether Angle's understanding of sagehood is really Confucian, see Ch. 1 of Angle (2009) and Ch. 2 of Angle (2012). See, also, Justin Tiwald (2011b)'s critical review and Angel's (2011) response.
} 
achieved, and that he is fully achieved in the realization of $l i$ (理). ${ }^{24}$ Angle translates $l i$ as "coherence," defining it as "the valued and intelligible way that things fit together"(32), and he as "harmony," defining it as "responsiveness to the contextually relevant coherence that structures one's situation"(69). Therefore, a sage's moral perfection is realized when his responsiveness to the contextually valued and intelligible way that things fit together in his situation is fully achieved. Angle expounds on relationships among these seemingly esoteric Chinese notions in various ways, including an analysis of the convoluted Neo-Confucian's metaphysics about qi (氣: matter energy), ${ }^{25}$ but for our current purposes, a part of "Zuo Commentary” (左傳 or 春秋左氏傳) ${ }^{26}$ in which Angle explains the concept of harmony will suffice. Consider this:

\section{CASE 1: THE COOK}

"Harmony is like a broth, wherein water, fire, vinegar, minced meat, salt, and plum sauce are used to boil fish meat. Cooking it over firewood, the chef harmonizes it, proportionating it with flavor: adding to what falls short and taking away from what is in excess. The nobleman partakes of it and thereby sets his mind in balance (ping: 平)"'(quote from Angle 2009: 62). ${ }^{27}$

\footnotetext{
24 This is a different word from the $l i$ (禮) that is typically translated as “ritual.” They are homonyms.

${ }^{25}$ For the metaphysical issues about $l i$ and qi (matter energy), see Ch. 2 of Angle's book (2009).

${ }^{26}$ Zuo Commentary is traditionally considered one of the most important commentaries on Spring and Autumn Annals (春秋), one of the Confucian Five Classics and one of the earliest Chinese historical records, which covers the period from 722 BCE to 481 BCE.

27 This passage was originally intended to discuss how perfection in political governance is achieved when a ruler and ministers balance and restrain each other. I believe that this passage can also shed light on our questions, perfectly in accordance with the original message of the passage.
} 
This ancient passage (compiled around 475-221 BC) uses a trivial culinary example to elucidate the Confucian view that "harmony" is a constitutively vital condition of "perfection." The perfect taste of the ancient Chinese broth emerges only when all relevant ingredients are harmonized or well balanced. The nobleman who seeks to be a sage learns from this analogy, realizing that the basic picture of a sage's moral metaphysics is not much different from the activity of cookingthat is, one's moral perfection emerges when one successfully balances relevant moral ingredients. We shall see in the next section that this culinary metaphor is useful for envisioning how the Chinese manager and officials, if they were Confucian sages, would balance two managerial ingredients: workplace rites and rights.

Spelling out the last term, "coherence" (li) — "the valued and intelligible way that things fit together"-will further clarify what sagely perfection represents. As Angle's translation, "coherence" (li), insinuates, in a sage's metaphysics there might be "many" coherent patterns of balancing moral ingredients, depending upon contexts, since, for sages, correct moral actions are the most apt responses to particular contexts. Sages, accordingly, would not invariably follow pre-determined patterns, rules, or principles of balancing moral ingredients irrespective of particular contexts. In this sense, Angle (2009: 208) points out that sagely moral perfectionism is deeply involved with a kind of moral particularism. This in turn signifies that a certain pattern of balancing moral ingredients, which could be considered valued and intelligible in one condition, might not be as valued and intelligible in other contexts. As we shall shortly see, the so-called "many" ${ }^{28}$ feature of "coherence" $(l i)$ is of great import for theorizing a non-ideal Confucian

\footnotetext{
${ }^{28}$ I call it the "many" aspect of $l i$, following the Neo-Confucian Cheng Yi's (1033-1107) abstruse but penetrating statement that " $i$ is one and distinguished into many" (quote from Angle 2009: 44).
} 
perspective. To see practical implications of the "many" aspect of $l i$, I suggest considering a simple variant of the culinary example.

\section{CASE 2: THE COOK IN AN NON-IDEAL CONDITION}

Imagine that you are the cook in the Zuo Commentary who wants to make the Chinese broth. You want to make it perfect, but unfortunately, you lack one necessary ingredient, say, the plum sauce. This year has been a bad year for the plum harvest. You wonder how you can make the best broth in the given nonideal environment.

This variant, though not original to the Confucian text, could—with the assistance of Angle's explication of sages' metaphysics we just learned—help us generate two key propositions of a non-ideal Confucian perspective that will be perfectly consistent with sages' moral metaphysics.

What is the cook supposed to do in Case 2? The cook is supposed to improve the taste as much as possible in the given circumstance. Assume, ex hypothesi, that an extra dash of vinegar will substitute for the plum sauce nearly or to some extent. The cook cannot make the exact same broth in the given circumstance. Note that the apt choice is often less than perfect in a non-ideal condition. Nonetheless, the substitution is the second-best option. Suppose that in Case 1-the ideal condition - the cook was supposed to use plum sauce with 1 dash of vinegar. Then, in Case 2-the non-ideal condition - the cook is supposed to add two dashes of vinegar, which would have been considered excessive in Case 1. In Case 2, if you cooked the same way as you had with plum sauce in Case 1 - namely, you did not add a second dash of vinegar, then the taste in Case 2 would not be good or might even be terrible. Therefore, if the cook in Case 2 were a sage 
who attempted to aptly respond to the particular situation, he would perceive, all things considered, that the contextually apt response to the given condition — that is, coherence (li) - is to add the extra vinegar.

Of course, cooking is not a simple arithmetic. It is an art. In our scenario, we simply assume that adding 1 dash of vinegar is the best option, but in reality no one can predetermine or tell you what the best substitution is without experiencing complex processes. To find out, the cook needs to possess relevant capabilities and character traits—e.g., commitment to the ideal soup, adequate discipline and apprenticeship. Again, the ability to aptly respond to given particular situations is the most important virtue of sages.

Now we can use the analogy to understand the balance of moral ingredients in non-ideal conditions. The variant in Case 2 reveals an important aspect of sages' moral metaphysics: that the balance of moral ingredients, through which true harmony can be realized, in non-ideal conditions could be different from that in the ideal moral condition - the first proposition of a non-ideal sagely perspective, which I shall call "The Proposition of 'Many."”

The Proposition of "Many": The apt coherence in a non-ideal condition could be different from that in the ideal condition. In other words, what is contextually undesirable in the ideal condition might possibly be contextually desirable in a non-ideal condition.

The Proposition of "Many" could imply, for our purposes, that the Confucian moral fact that Confucians should primarily utilize social rituals as an ideal means but not rights in the Confucian ideal condition such as family or intimate communities does not exclude the 
possibility that rituals sometimes must necessarily be balanced with rights as a second-best means in non-ideal contexts like the modern workplace.

An important question emerges: how would sages determine whether or not the apt pattern at the modern workplace would be one of balancing rites with rights. The so-called "one" 29 aspect of coherence ( $l i$ ) could answer the question, I believe. Angle discusses in detail that the neo-Confucians who most systematically developed sages' metaphysics, including Zhu Xi (1130-1200), emphasized not just the "many" aspect of coherence (li), but also its unity and consistency as fundamentally important. Consider Zhu Xi's frequently-quoted statement, which he adapted from a Buddhist expression:

The Buddhists say, "The one moon is commonly reflected in all pools of water; in all pools the moon is the same moon"; herein the Buddhists have glimpsed the coherence of the Way (Zhu 1997: 357; quote from Angle 2009: 45).

To grasp what Zhu Xi means in this passage, I find Angle's commentary helpful:

Coherence is that which explains the Way: finding the particular 'ordered pattern' in a situation is to see and feel coherence, and thus to be drawn along the Way. $[\ldots][S]$ agehood means perceiving-and-acting in accord with the Way, not standing still on the road. It means having a dynamic relationship to $l i$ : responding coherently in ways that generate situations with evermore inclusive coherence (italics mine: 43 ).

\footnotetext{
${ }^{29}$ I call it the "one" aspect of $l i$, following the Neo-Confucian Cheng Yi's (1033-1107) statement.
} 
As I understand Angle's commentary, the unity thesis implies that particular patterns of balancing ingredients that are apt in different contextual conditions must not be idiosyncratically fragmented from each other. ${ }^{30}$ They must be consistently and coherently situated along the same journey or directed toward the fundamental ideal, which is often called the "Way." With this in mind, let us return to the cook in Case 2, who attempts to improve the taste by mostly closely replicating the taste of the soup in Case 1. The perfect taste in Case 1 plays the accommodative and regulative target role in Case 2. In other words, the culinary legitimacy of a substitute in Case 2 is assessed to the extent that the cook attempts to improve the taste by coherently recreating the perfect taste of the soup with plum sauce in the ideal condition-Case 1 . This analogy is perfectly consistent with the unity thesis of coherence ( $l i)$ explicated above: that apt patterns of balancing things must not be fragmented forms but rather be coherently positioned along the same journey. Then, for sagely moral metaphysics, it can be said that the moral perfect in the Confucian ideal condition plays an accommodative and regulative target role for non-ideal conditions. ${ }^{31}$ Therefore, it follows that a sage's apt responses to non-ideal conditions would be those that attempted to coherently and contextually best realize the fundamental Confucian

\footnotetext{
${ }^{30}$ Consider also Zhu Xi's own commentary: "Someone asked what the difference is between the Way and coherence. Master Zhu said: "The Way is like a roadway. Coherence is its ordered pattern." It was also asked if this is anything like the grains in wood, and Master Zhu answered: "It is." It was further noted that, if this is the case, then the Way and coherence appear to be alike, and Master Zhu said: "The word 'Way' is vastly inclusive, while coherence is the many coherent veins within it." He also said: "The Way is vast and large. Coherence is minute and detailed" (Zhu 1997: 90; quote from Angle 2009: 42-3).

${ }^{31}$ This way of understanding, though developed differently, corresponds to various contemporary western philosophers' views on the target role of ideal theory for non-ideal theory (Phillips 1985; Rawls 1971; Simmons 2010).
} 
ideal. ${ }^{32}$ So we arrive at the second proposition of a non-ideal Confucian perspective, which I shall call "The Proposition of 'One."”

The Proposition of "One": The pattern of coherence of a person's action in a nonideal condition is determined in light of how the person attempts to aptly facilitate the perfect in the ideal condition. In other words, what is ethically correct for a person in a non-ideal condition is determined in light of how aptly the person attempts to facilitate or realize what is ethically correct in the ideal condition.

The Proposition of "One" implies, for our purposes, that a person's endorsement of rights as well as rituals in non-ideal conditions like the modern workplace must be assessed to the extent that her act of combination coherently attempts to help workers cultivate and realize that which Confucians are supposed to cultivate and realize in the ideal Confucian condition: in our context specifically, these are the particularistic personal ties on which the development of most important Confucian virtues depends. In the next section, I will attempt to show that, at the workplace, rituals when balanced with rights could often help workers realize family-like intimate, affective communities more successfully than rituals observed only without rights.

${ }^{32}$ One might wonder if, in a world with no plum sauce, a sage might not achieve a different kind of fully perfect soup. If a sage could achieve two different kinds of fully perfect soup, then there might be a dilemma case in which both options are compelling. This is relevant to our questions, because, if so, it could signify a metaphysical possibility that a different kind of ideal, other than the ideal of family-like intimate community, might be appropriate at the workplace even within the framework of Confucianism. For more detailed discussions, see, Angle (2009: Ch. 6). In this article, I assume, following Bell's (2008: 76) contention that "a basic assumption of Confucian ethics is that the moral life is possible only in particularistic personal ties," that the ideal of family-like intimate communities is one of the most critical ideals in the Confucian tradition. 


\section{WOULD A CONFUCIAN SAGE APPRECIATE RIGHTS AS WELL AS RITES AT}

\section{THE WORKPLACE?}

In this section, I answer the question of what happens if the Chinese plant manager and officials take Confucian sagehood seriously. As previously shown, sages would choose the apt response to the non-ideal context of the modern workplace. As the two propositions of the nonideal Confucian perspective suggest, sages would choose a pattern of balancing moral ingredients, which would aptly help workers realize the Confucian good—specifically, the ideal of family-like or community-like intimate, affective human relationships.

What ingredients do sagely managers and officials have for their managerial recipes? Countless ingredients undoubtedly exist, but we will explore two principal components, to which Confucians have paid the most attention: most recently, rights, and traditionally, rites. We then have four possible patterns of balancing these ingredients: i) only social ritual; ii) only rights; iii) rights and ritual; and iv) a null set. ${ }^{33}$ In what follows, I will attempt to explicate why sages would perceive the third option — balancing both ingredients - as the appropriate ethics strategy for the workplace, focusing on comparing i) and iii) —as it seems uncontroversial that ii) and iv) are already worse options than i) or iii) for promoting intimate communities.

\footnotetext{
${ }^{33}$ One might contend that my argument in this article is incomplete, because I do not consider alternatives to rituals and rights. If I want to make an argument that balancing rites with rights is mandatory, I need to show, as a logical matter, that the combination of these two is the best among all others. I admit the logic. Hence, as a logical matter, my argument is, more strictly speaking, that it is tentatively confirmed that rites must be necessarily balanced with rights at the workplace, and if a better alternative is observed, then my argument will be rejected. Nonetheless, I do not believe that this is a fatal weakness of my argument. First, since it is hopeless to inductively explore all possible alternatives, it is a convention that researchers choose alternatives that are paid most attention. Second, since this form of argumentation through tentative confirmation is, as Karl Popper (2002) points out, widely accepted in a broad range of natural and social sciences, which obviously attempt scientific objectivity and rigor, my argument at least should deserve a similar reception.
} 
Since most of us have not really experienced a workplace where no rights are allowed but only social rituals are heavily observed, I suggest considering the following thought experiment for our purposes:

\section{CASE 3: THE CEREMONIAL WORKPLACE WITH NO RIGHTS}

Imagine the opening day of a mobile phone manufacturing plant in China. This workplace comprises a diverse set of average Chinese blue-collar workers, white collar-workers, low and upper-level supervisors or managers, and the plant director. Some are greed-driven egoists, some are altruists, and most are probably in between. Greed-driven egoists sometimes do not hesitate to offend or harm others through, for example, physical violation, discrimination, breach of trust, exploitation, humiliation, oppression, and ill-mannered treatment, if they perceive those acts to be beneficial to themselves. Other types of people occasionally (though not as often as the egoist) decide to offend or harm others in order to protect their own interests. In this workplace, various social rituals such as corporate anniversaries, seasonal events, and recognition rites are regularly held, and rituals of greeting, posture and other countless little rituals ${ }^{34}$ are encouraged, and all workers attend the occasions with low-level/upper-level managers and the plant director. But the Chinese workers are not allowed to exercise any labor rights recommended by the ILO (International Labor Organization).

\footnotetext{
${ }^{34}$ For more detailed discussion of specific rituals in China, see Bell (2008: Ch. 3). For more general discussion of Confucian rituals, see Ing (2012), Kim \& Strudler (2012), Sarkissian (2010). For discussions of both western and eastern rituals, see Solomon, Lo \& Fan (2012), Sarkissian (2010).
} 
My analysis below is designed to show how allowing some form of rights in Case 3 could help the Chinese workers cultivate attitudes toward each other that better approximate the Confucian ideal of family-like, intimate and affective communities. As such, Confucian sages would balance rites with rights. Of course, rights are a complex and often technical moral and legal concept (see e.g., Waldron 1984; Wenar 2003, 2005, 2008), and it is beyond the capacity of this article to provide detailed technical discussions of different functions, rationales, and incidents of rights. Nonetheless, I will attempt to conceptually delineate three fundamentally different, though interrelated, functions of workplace rights which I believe could be helpful to promote and improve intimate and affective relationships in a context like Case 3: the facilitative role, the assurance role, and the restorative role. Note that the purpose of this analysis is not to show that rights could allow the Chinese workers to have attitudes that sufficiently correspond to the Confucian ideal of family-like relationships. In non-ideal contexts, the apt is less than perfect. Instead, the purpose of this analysis is to show that by allowing some forms of rights in Case 3 the plant director can attempt to help the Chinese workers promote interactions that approximate the Confucian ideal of intimate communities better than disallowing rights.

THE FACILITATIVE ROLE: Let me begin with the contemporary Confucian Daniel Bell's (2008: Ch 5) autobiographical essay about his relationship with a domestic worker in his Hong Kong house. ${ }^{35}$ The essay, although written as a personal narrative, explores a serious question that all authentic Confucian employers should ask, by vividly describing Bell's anguished efforts to answer the question of how Confucians who see their moral life ideal as incompatible with rights should treat their domestic workers at home. As a committed Confucian, Bell (83) recognizes that "excessive rights focus can undermine affective ties between employer

\footnotetext{
${ }^{35}$ It must be said, to avoid an unnecessary sense of incongruity, that both Bell and his wife work, and hiring a domestic worker is common in Hong Kong.
} 
and employee," but he also recognizes from his own experience that "it would be a mistake to assume that there is always a trade-off between the protection of legal rights and family-like affective relations. In some cases, rights can actually promote affective relations" (82-3). One example he briefly mentions is the right to long-term employment (two or three years) for domestic workers, ${ }^{36}$ which he believes would make domestic workers "more likely to stick with their employers" (83). Bell's suggestion seems applicable in the context of Case 3 as well.

A skeptic might complain that the relationships between domestic workers such as nannies or housekeepers and their employers are qualitatively different from the industrial relationships in the large-scale workplace of Case 3. I do not deny that the facilitative function of the right to a secured period of employment could likely be more effective in promoting familylike, affective relations in the case of domestic workers than in that of larger-scale workplaces. However, the contextual difference would not nullify the indirect relationship-building effect, since the Chinese workers in Case 3, if afforded the right to long-term employment, would still be better positioned than the workers without the rights to develop affective, intimate relationships. Compare the following two scenarios. Imagine that you are a Chinese employee of the phone manufacturing company in Case 3, and you and all of your coworkers, including managers, are daily-contract workers without the right to long-term employment beyond one day. In other words, you do not know whether you can work here tomorrow or not. It follows that you do not know whether you will stand next to your supervisor in the workplace ceremonies (e.g., various parties) tomorrow, nor do you know whether your coworkers will be here to participate in the ritual. As a result, you would probably hesitate to reach out to others in the rituals. Now imagine that you know that all the workers attending the rituals in Case 3 are entitled to a

\footnotetext{
${ }^{36}$ The right to long-term employment does not mean that employees cannot quit during the specified period or that employers cannot fire employees with legitimate reason.
} 
reasonable period of long-term employment, which does not have to be like the lifetime employment (shushin kyoyo) offered in Japan. Let's say instead that the workers in Case 3 signed a labor contract ${ }^{37}$ that specifies an initial employment term of 2 years and requires 30 days' written notice of termination. It is not given that such long-term employment contracts would necessarily help the workers develop better relationships with the plant director, just as tenure track contracts do not automatically help professors develop personal relationships with the president or provosts. But it seems more obvious that the Chinese workers with longer-term contracts would have better reason to promote and improve affective relationships with each other and also with low/upper-level supervisors or managers. Hence, allowing rather than disallowing such a right in Case 3 could be a better option to help the workers aptly approximate the Confucian ideal.

It is an empirical matter whether the Chinese workers would really develop better relationships as a result of this employment right. My argument could potentially be corroborated by rigorous lab experiments or longitudinal studies designed to show that workplace rituals when balanced with a right to long-term employment help workers develop intimate, affective relationships better than when only rituals are observed like the workplace as in Case $3 .{ }^{38}$ Nevertheless, my argument must not be undercut by the empirical challenge, because it is still

${ }^{37}$ According to a recent study (Wong 2011), about 50\% of migrant workers in China have not signed labor contracts.

${ }^{38}$ Although I admit that empirical testing of the hypotheses I have created would possibly corroborate my theoretical arguments, I am partly skeptical about such empirical endeavors for two reasons. First, since human relationship development is a process that takes place over a period time, a longitudinal study seems most appropriate to the hypothesis testing, but a longitudinal study or survey needs a real workplace where only rituals are observed as a control group, which seems very difficult to find in modern workplaces, even in China. Second, in lab experiments, participants would be statistically meaningfully manipulated to hypothetically assume that they work for a company where only rituals are observed as a control group. Then, it seems unclear what substantial differences this sort of hypothetical imagination can make from the hypothetical thought experiment conducted in this article. 
true, in principle, that the workers would have better reason to promote and improve affective relationships when enjoying the right to longer term employment, regardless of whether they actually developed those relationships or not. Namely, if the workers were guaranteed a right to work for a longer term, their underlying perspectives about other workers, supervisors, and the plant director, would be in a position to allow them to better approximate the Confucian ideal of intimate and affective relationships.

THE ASSURANCE ROLE: The Confucian ideal of intimate community promotion and improvement is not limited to the right to long-term employment alone. Broader kinds of workplace rights could circumstantially help to cultivate attitudes that approximate the Confucian ideal of intimate communities better than when only workplace rites are observed. Let us return to Bell's (2008) essay. In addition to discussing longer terms of engagement, he also briefly compares the working situation of domestic workers in Hong Kong to that of Chinese workers in other mainland Chinese cities. According to Bell, domestic workers in Hong Kong typically work with contracts regarding minimum wage and health and accident insurance, whereas domestic workers in other Chinese cities typically work without contracts. Bell says that such contracts could also help to promote the development of family-like relations between employer and domestic worker. He does not further speculate, but I maintain that his argument could also be applicable to Case 3. I argue that various kinds of workplace rights in general could function as "assurance" for developing further relationships. To see this, I suggest the following thought experiment:

CASE 4: THE TERRIFIED PSYCHIATRIST BEFORE A CRIMINAL 
Imagine that you are a psychiatrist who counsels prisoners in Yanbian. It's the first day of your first job. You sit in a dark and chilly counseling room waiting for Chinese prisoners you have never met. A former member of the Axe Gang in Shanghai with dragon-shaped tattoos on both arms walks in the door and greets you by extending his hand for a shake as a greeting ritual. You hesitate, afraid of a possible attack.

Now consider a revised version of this example.

\section{CASE 5: THE ASSURED PSYCHIATRIST BEFORE A CRIMINAL}

Suppose that you are in the same situation but with one difference: a prison guard with a hulking physique stands next to you. You are not completely relaxed, but you feel that the guard's presence assures some degree of safety, so you more comfortably shake hands with the prisoner. As you talk with him during the counseling session, you realize that the handshake was a sincere gesture of friendliness. You regret that if the guard had not been there to assure your safety, you would not have taken the chance to respond amicably to the prisoner.

I submit that the employees in Case 3 are often like the terrified psychiatrist in Case 4. Even though the employees attend workplace rituals, rights do not protect them, just as a guard does not protect the psychiatrist. Broad labor rights could function like the prison guard in Case 5. In the context of the non-familial workplace, rights to safe and healthy environments, fair treatment, minimum or lawful wage, minimum insurance, and basic preventive, protective and 
compensatory rights, including a right to organize, could generally assure the Chinese workers in Case 3 that they would not be arbitrarily exploited, unfairly discriminated against, coerced, attacked, harmed, or hurt; and even if they were accidentally or incidentally harmed or unfairly treated, they would be guaranteed reasonable and transparent ways for recovering losses. In many occasions, then, the assurance of broad kinds of rights could galvanize the Chinese employees to interact more comfortably with their employers, managers, and other workers even in social rituals. For instance, if the plant director in Case 3 did not respect any rights of the sort that could assure the workers' minimal safety, grievance, recovery, and compensation, the workers realistically would have a reason to see him less as a person with whom they could develop better relationships through social rituals. In contrast, if the director guaranteed such rights, the Chinese workers would be better positioned to view the director as a person with whom they could potentially promote better relationships. Such improvements would not be limited to the workers' interactions with upper-level supervisors, managers or directors; in fact, the workers who were guaranteed rights of assurance would have a reason to feel more relaxed while interacting with low-level supervisors as well as same-level workers, because they would know that others could not easily attempt to arbitrarily or unfairly treat them.

THE RESTORATIVE ROLE: One more way that rights could help promote affective relationships in non-ideal conditions like the workplace in Case 3 is their restorative function. As Ihara (2004) and Strudler (2008) have already noted, Confucians' communitarian approach to addressing wrongs by appealing to role-dependent obligations grounded in the communal good cannot properly work in non-ideal Confucian contexts like Case 3, where constituents aim to promote conflicting goals, interests, and purposes, and thus render conflicts almost in-eliminable. But if the Chinese workers were allowed to exercise relevant rights when necessary, then they 
would be able to address wrongs by specifying what rights were violated. How, then, can this corollary help promote and improve affective relationships? The option to address wrongs is sometimes an essential component in restorative or conciliatory activities. Suppose that last night you and your manager attended a widely observed Japanese, Chinese, and Korean workplace ritual, i.e., Karaoke Night. ${ }^{39}$ Today, the manager suddenly and unabashedly exploits ${ }^{40}$ you by ordering you to work compulsory overtime. Since you and the manager do not yet reside in the Confucian ideal condition, you cannot appeal to the communal good or his role obligations. Therefore, you cannot address the wrong. Now suppose that you have been allowed a right not to work compulsory overtime. Consequently, you can say that the manager failed to respect your right, by failing to satisfy the correlative, a negative duty not to order compulsory work overtime, and so his act was a moral wrong. Now, once the wrong has been addressed, the wrongdoer (the manager) has an option to acknowledge his fault or wrong to you. An apology, inter alia, is a humble acknowledgement of wrong or fault (Smith 2008), as the phrase "I'm sorry. I was wrong" depicts. An acknowledgement of fault through an apology is a powerful social and moral phenomenon, and often an indispensable ingredient in restoring relationships with others (Lazare 2004). ${ }^{41}$ Of course, just because a victim has the option to address a wrong does not mean that the wrongdoer will automatically apologize. Similarly, just because the wrongdoer apologizes to the victim does not mean that the victim will forgive. Finally, even if the victim forgives, the wrongdoer and victim will not perforce harmoniously conciliate and move on to a better

\footnotetext{
${ }^{39}$ Karaoke Night is a common workplace ritual in Asian countries. For more commonly observed workplace rituals in Asian countries, see Bell (2008: Ch. 3).

${ }^{40}$ For various accounts of exploitation, see Snyder (2010).

${ }^{41}$ Words and deeds in apologies (e.g., "I'm sorry" and "I was wrong") may sometimes be considered petty and trifling, but the smallest endeavors - when meeting certain conditions that render them felicitous (Lackoff 2000; Searle, 1969) — can expressively heal wrongfully damaged relationships in valuable ways (Radzik 2009; Walker 2006).
} 
relationship. Nonetheless, having the option to address wrongs provides victims and wrongdoers an opportunity or hope to integrate with each other through the process of "making up." If there were no such option from the beginning, there would be no hope for improved relationships. If fostering hope rather than impeding is, as Margaret Walker (2006) says, a valuable moral progress in the restorative context, then, since restorative effects can sometimes be enormously helpful for promoting intimate and affective communities, having the option to address wrongs in Case 3 through the idea of rights would create a better workplace environment for all those involved.

Now, imagine that, at the ceremonial workplace in Case 3, the Chinese workers are allowed to embrace various rights that can help them promote and improve the Confucian ideal of intimate communities. They are institutionally guaranteed some reasonable period of employment. They need not worry that they might not see their supervisors or fellow workers tomorrow. Various rights to minimal safety institutionally protect them. They need not suspect that their supervisors or plant director or co-workers might easily attempt to discriminate, exploit, oppress, or humiliate them. They now have an option to remedy wrongs, should they occur, through restorative processes, which essentially include the acknowledgement of wrong, which could be addressed with the existence of rights. Overall, the Chinese workers who attend social rituals with the institutional protection of such rights would often be better positioned to develop the Confucian ideal of affective, intimate personal relationships than the workers who only observe social rituals without the protection of rights in Case 3.

\section{OBJECTIONS}


In this section, I attempt to deepen my argument by responding to possible important objections.

\subsection{AN OBJECTION ABOUT THE NEEDLESSNESS OF SAGES}

One might question what role the concept of sage plays in my argument. Without the concept, the same argument can be made, as follows. Premise 1) Confucians have reason to act in ways that best develop important Confucian values and ideals. Premise 2) Workplace rights can help to promote and improve intimate communities in workplaces. Conclusion) Therefore, Confucians have reason to allow rights in workplaces. My analysis of the sage, hence, is needless, the critique can conclude. A critic might also say that while the improvement of intimate communities through rights is most important in my argument, my focus on the sages can distract managers from paying attention to the roles rights can play to promote intimate communities at the workplace. This is a valid concern, and addressing it will help the reader better understand my argument.

The concept of sages in my argument plays the role of a ladder that the Chinese managers and local officials can discard after they have climbed up. The non-ideal Confucian perspective developed from Neo-Confucians' understanding of sages leads the managers and officials to understand that Premise 1) above can be developed within their own moral tradition, which can show them the soundness of Premise 1). Before using the ladder, they have difficulty understanding how to behave as Confucians in non-ideal Confucian conditions like contemporary Chinese factories. After they climb up the ladder, at which point they can see the workplace from the non-ideal perspective, they realize that Premise 1) is itself reasonable and cogent without necessarily going back to the concept of sagehood. Thus, now they can throw away the ladder. Nonetheless, the activist, Jayne, probably has practical reason to appeal to the 
sage to persuade the Chinese manager and officials. It can be strategically more effective to appeal to the concept of sages in Confucianism-influenced cultures than to appeal to the validity of argument or the desirability of certain states of affairs. In Confucian cultures, sages are regarded as the highest moral authorities not only by Confucian scholars but also by ordinary people. In such cultures, it is a common pattern in moral edification in family or school to say, "Sages (or gentlemen) once said...." and it has moral authority. Throughout the Confucian tradition, in fact, it is distinctive that many important classical textbooks do not directly provide arguments in a typically Western sense of critical thinking (Bell, 2008: Ch.7). Rather, a most commonly used argumentative method found in Confucian classics is to provide moral exemplars who lived arguments (Olberding, 2011).

\subsection{AN OBJECTION ABOUT ANYTHING-GOES}

Given my perfectionist argument that Confucians have reason to appreciate some kinds of rights, if they are extrinsically useful for the Confucian ideal, whether they are originated in the West or not, one might ask, "Would Confucian sages appreciate whatever led them to their ideal, no matter what?" The critic might ask us to forget about Confucianism for a moment and consider that we want a world in which everybody is treated as equal. We are egalitarian perfectionists. But we know that one best way to bring about equality is to make some number of workers slaves for a few years, so that the economic preconditions for equality can be achieved. There are no slaves yet. As egalitarian perfectionists, should we then promote slavery? Apparently, as a matter of logic, the answer should be positive. If the underlying structure of the sage's moral perfectionism is the same as the egalitarian perfectionism just delineated, then the sage's perfectionism should also face the same absurdity. 
There are two starkly different answers to the question of whether the egalitarian should temporarily promote slaves or not. If the egalitarian is a consequentialist, then the answer is probably almost positive, ${ }^{42}$ since consequentialism is largely an outcome-oriented perspective (Smart 1973). But the egalitarian does not necessarily have to be a consequentialist (e.g., Scheffler 1982). If he were a deontological egalitarian, the answer would not necessarily be positive. For the deontological egalitarian, equal treatment is a constitutively necessary condition for the realization of an egalitarian society. Therefore, it does not make sense as a matter of principle that one would seek an egalitarian society while at the same time making others slaves. What this shows is that the good sought in a deontological version of perfectionism nonconsequentially constrains the process through which one achieves the good.

Next, suppose that we are Confucian managers or officials who have a conviction about the moral authority of sages. One of the best ways to bring about intimate community is to make some people slaves for a few years, so that the economic preconditions for an intimate community can be achieved. Then should we promote such a condition? My answer would be a definite "No." As we have seen, the answer depends upon whether the Confucian perfectionism is (blindly) consequentialist or not. There are many versions of Confucianism, but it is widely accepted that Confucianism must be construed as a non-consequentialist moral account (Angle 2014; Strudler 2009). ${ }^{43}$ As such, Confucian perfectionism can avoid the critic's challenge. It can be said that the realization of intimate community is partly constitutive of treating others in

\footnotetext{
${ }^{42}$ For a different opinion, see Green (1986).

${ }^{43}$ In his recent book, Chan (2014: 31) says that some dimension of Confucian perfectionism is consequentialist, although he also says, "it is not the maximizing form of consequentialism." I agree with much of what we says in the book, but I disagree with his instrumentalist interpretation of Confucian perfectionism. I believe, as I explain above, that Confucian perfectionism can be construed as non-consequentialist and that consequences matter in deontological ways.
} 
certain ways, e.g., treating them humanely, decently, civilly, etc. Thus, the achievement of the Confucian ideal of intimate community regulates that we consistently treat others in certain ways even in non-ideal conditions. In fact, this response is already reflected in the details of sagehood considered in this article, especially where I expound on the "Proposition of One" that emphasizes the regulative role of the ideal and the consistent unity of different modes of coherence, which implies that wrongdoings, inconsistent with the Confucian ideal, cannot be legitimate ways for one to realize the ideal. From this perspective, Confucian sagehood must not be construed as a simple outcome-oriented account, blind to processes through which to achieve the regulative target.

\subsection{AN OBJECTION ABOUT INCONSISTENCY}

One might point out, then, that any justification of rights would compromise the "Proposition of One," because appreciating rights is, in principle, inconsistent with the Confucian ideal of family-like intimate community; therefore, attention must be paid to the ideal means - namely, social rituals — rather than to endorsing rights, in order to change the workplace into a more family or clan-like place. In fact, some scholars such as Adam Bailey (2011) make such a point. Bailey argued that if the Confucian ideal community is really an ideal for Confucians, and it is a non-consequentialist account, as the "Proposition of One" signifies, then any compromise of it is inconsistent with the Confucian ideal as a matter of principle, and Confucians should stick to refusing rights at the workplace.

I agree with the core of Bailey's point, because I also believe that any compromise of the Confucian ideal is inconsistent with the ideal—a tautological truth. But I do not think that his objection counters my argument. Instead, I think that his objection errs in how it identifies the 
way Confucian sages determine whether a certain act is consistent or inconsistent with the ideal; consistency or inconsistency with the Confucian ideal is, as explained above, not pre-determined, but rather, contextually determined. In a nutshell, what is consistent with the ideal for sages is what is contextually the apt response to the given environment for the realization of the ideal. In other words, what is inconsistent with the ideal is what sages would perceive as not apt for the given circumstance. Underlying Bailey's criticism could be a misguided view that a correct act for Confucians is determined regardless of particular contexts. The Confucian norm, "Do not treat others as rights-bearers" is not an end itself, but instead a perfectionist means to best promote intimate communities in the Confucian ideal condition. The norm does have its relevance in the Confucian ideal condition, but not for the norm's sake. The force of the norm would be dramatically weakened in a context where, for instance, strangers or adversaries met in a non-ideal condition like Case 3. In Case 3, the balanced view of treating others as rightsbearers as well as rites-bearers could better help workers realize the Confucian ideal of intimate communities than could the unbalanced view of treating others only as rites-bearers. ${ }^{44}$

\subsection{AN OBJECTION ABOUT INSTABILITY}

\footnotetext{
44 The sage's non-ideal theorizing can be alternatively understood as a theory of second-best choice (e.g., Goodin 1995). To use Robert Goodin's example of buying a car, if you want to buy a new silver Rolls Royce but the dealer does not have any available, it does not follow that you may prefer a new silver Ford (a car like your ideal car in two out of three respects) over a oneyear-old black Mercedes (a car unlike your ideal car in every respect). The underlying message of the second-best theory is that we should not naively think that it is better to have less of goods that are ideally undesirable. Instead, we must think about what we fundamentally want to see in the condition that we take to be ideal. In Goodin's example, what the buyer wants to have in the ideal condition is not the car itself. The prestige and satisfaction that the car can give him could be his ideal. In a like manner, fewer rights is not the ideal itself for Confucians. The fundamental ideal is more family-like intimate communities.
} 
The critic could also rebut my argument because the workers' rights might be unstable. The main rationale for sages to appreciate some kinds of rights, as I have expounded, is that they can better help the Chinese workers in Case 3 realize the Confucian ideal than can rites alone. This implies two things. First, sages would not appreciate rights that cannot provide such a communitarian function. Therefore, the critic might argue that a) the Confucian workers would not enjoy the broader kinds of rights that western people enjoy. Second, since the rationale is the instrumental power of rights, the foundation of rights is circumstantial, rather than definite. As Ronald Dworkin (1984) argued, at least in the West, rights are like "trumps" that have the definite power of overriding other considerations, and the definite power of rights is, especially in the natural right tradition, intrinsically constitutive of humans' moral worth or dignity. Given the instrumental feature of the sage's rationale, the critic might argue that b) the Chinese manager or officials could arbitrarily interpret that certain rights are not helpful for realizing the Confucian ideal and values. I do not see any of them to be a serious problem for the sagehoodbased argument.

It is unclear to me whether there is good reason to appreciate the value of rights other than the rationale that rights are good and helpful for people to fulfill their valuable "goods." If it is true that family-like intimate community is one of the most cardinal goods for the Confucian workers, and if some kinds of rights that the western workers have are in fact inimical to such a good, then it is unclear why the Chinese workers should enjoy having those rights and how those rights could protect their moral worth. Furthermore, not all Western accounts of rights would find the sage's view necessarily absurd, especially, given the widely accepted western idea that a person A's right to something X presupposes that A has interest in X (e.g., Feinberg, 1984; see also Kramer, Simmonds, and Steiner 2000). The Western rights theorists who endorse the 
interest-based account of rights would not define kinds of rights, in which the Confucian workers do not have interest, as their rights. Second, whether or not a right is good for fulfilling a certain ideal is an objective matter that must be rationally reasoned. Hence, an employer's arbitrary opinion should not count as a legitimate interpretation. Still, the critic might want to argue that, in reality, reasoned argument can easily be replaced by power. I do not wholly disagree, but this is not the unique problem of the sage's account of rights. Even in the western world, deciding which entitlement should be recognized and institutionally implemented as a right is often a political process where many non-moral considerations are at play. Hence, the sage's view of rights should deserve at least the consideration that western accounts receive.

\subsection{AN OBJECTION ABOUT BAD SIDE EFFECTS}

Additionally, the critic might want to point out that I have ignored the potentially bad side effects of rightful claims. Consider the following scenario in which the critic might believe rituals and rights are in tension with each other:

\section{CASE 6: THE TENSION}

Suppose that social rituals have been balanced with rights for five years in Case 3 . A Chinese engineer and his supervisor have developed quite a good informal relationship - say, a workplace or business friendship (guanxi). The Chinese supervisor must lay off some workers on his team, and he realizes that including the engineer among those laid off is the best choice in the circumstance..$^{45}$ The supervisor hesitates but eventually officially announces the decision. The engineer

\footnotetext{
${ }^{45}$ For a more general discussion about ethical issues in lay-offs, see Kim (2014).
} 
responds by exercising the relevant rights he has at his disposal, such as a right to grievance.

I do realize that the informal and personal attitudes the Chinese supervisor and engineer have developed for years are in tension with the rights perspective that infuses the formal and impersonal attitudes that they have used. I also realize that such a tension is the key to some of the worries in the literature (e.g., Tiwald, 2011), that is, that the mere presence of rights might undermine possible progress toward a more community-like relationship. Yet, the pattern of balancing the two would still be the contextually best response in most non-ideal contexts. The two parties in Case 6 have roughly three options: i) withdrawing a rights regime and merely relying upon their informal relationship to solve the problem about the layoff; ii) withdrawing their informal relationship and simply moving forward to chilly litigation; iii) admitting that such tension is a part of the messiness that will endlessly challenge them in non-ideal conditions like the workplace and trying to best reconcile the tension. Clearly, iii) would still be the best choice. In option i), the two parties would merely treat each other as rites-bearers alone. This view, through the aid of rituals, might work, but not always faithfully in non-ideal conditions like the workplace; realistically, it has limitations. For instance, once rights are nullified and the two parties' conflict becomes severe, it could be likely that the hierarchically higher party wants to dominate the scene through power, which might result in an irrevocably broken tie between them-a significant Confucian loss. This problem could be lessened if the view of rights-bearers were balanced with the view of rites-bearers. In option ii), the two parties would entirely distance themselves from their personal ties and exercise only rights, as though they were adversaries at a civil court. Obviously this, too, is a poor option in terms of realizing intimate communities. 
Although option iii) would not completely eliminate the tension, sages would keep making efforts to balance the two systems - given that this sort of tension is unfortunate and almost ineliminable in non-ideal contexts like the modern workplace. Perhaps they would seek viable ways to at least lessen the tension between the views of rights-bearers and rites-bearers. ${ }^{46}$

\subsection{AN OBJECTION ABOUT IMPERFECTION}

Finally, one might ultimately express fundamental skepticism about the whole premise of this article, given that the tension between the two views - employees as rights-bearers and ritesbearers - would not be eliminated, leaving the modern workplace unlike the Confucian ideal condition. Since promoting family-like intimate, affective relationships at the workplace is a hopeless vision, any efforts for it are also hopeless. I both agree and disagree. I agree, because I admit that completely transforming the modern workplace into the Confucian ideal condition is almost unachievable under the current capitalist regime, unless we shift the economic paradigm to a new one more favorable to the Confucian ideal. Nonetheless, this gloomy reality does not make a sincere effort to develop more intimate communities at the workplace worthless. If we have an ideal, as John Simmons (2010) pointed out in a recent debate over the role of ideal theory, we can evaluate between circumstances which one is closer to the ideal. Some business organizations have more family-like cultures, while others have more market-like cultures (Pfeffer 2006). If we have an ideal of family-like affective communities, we can meaningfully discuss which workplace is better than others, although neither is completely family-like nor market-like. In fact, what we have explored thus far in this article is a journey to find out how to

\footnotetext{
${ }^{46}$ Perhaps something similar to conferencing, dialogue or mediatory methods often suggested in restorative justice scholarship (Braithwaite 2000) could help the engineer and the supervisor. Interestingly, Angle also briefly touches upon the positive role of mediation methods in politics and litigation at the end of his book (2009: 219; see also 2012: 143).
} 
more closely approximate the Confucian ideal of family-like intimate community in a non-ideal condition - the modern workplace.

\section{Works Cited}

Ames, R. T. (1988). Rites as rights: The confucian alternative. In L. S. Rouner, Human rights and the world's religions (pp. 199-216). Notre Dame, IN: University of Notre Dame Press.

Ames, R. T. (2011). Confucian role ethics: A vocabulary. Honolulu: University of Hawai'i Press.

Angle, S. C. (2012). Contemporary confucian political philosophy. Malden: Polity Press.

Angle, S. C. (2002). Human rights and chinese thought: A cross-cultral inquiry. Cambridge, UK: Cambridge University Press.

Angle, S. C. (2011). Reply to justin tiwald, Dao 10:237-239.

Angle, S. C. (2009). Sagehood. New York: Oxford University Press.

Angle, S. C. (2014). The analects and moral theory. In A. Olberding, The dao companion to the analects (pp. 225-257). New York: Springer.

Angle, S. C., \& Slote, M. (2013). Virtue ethics and confucianism. New York: Routledge.

Arnold, G. D. (2013). Global justice and international business. Business Ethics Quarterly, 23(1): $125-143$.

Arnold, G. D., \& Bowie, N. E. (2007). Respect for workers in global supply chains: Advancing the debate over sweatshops. Business Ethics Quarterly, 17(1): 135-145.

Arnold, G. D., \& Bowie, N. E. (2003). Sweatshops and respect for persons. Business Ethics Quarterly, 13(2): 221-242. 
Bailey, A. D. (2011). Confucianism-based rights skepticism and rights in the workplace. Business Ethics Quarterly, 21 (4), 661-672.

Bell, D. A. (2006). Beyond liberal democracy. Princeton, NJ: Princeton University Press.

Bell, D. A. (2008). China's new confucianism. Princeton: Princeton University Press.

Bell, D. A., \& Chaibong, H. (2003). Confucianism for the modern world. New York: Cambridge University Press.

Bishop, J. D. (2012). The limits of corporate human rights obligations and the rights of for-profit corporations. Business Ethics Quarterly, 22(1): 119-144.

Braithwaite, J. (2000). Survey article: Repentance rituals and restorative justice. Journal of Political Philosophy, 8 (1), 115-131.

Campbell, T. (2006). A human rights approach to developing voluntary codes of conducts for multinational corporations. Business Ethics Quarterly, 16(2): 255-269.

Chaihark, H., \& Bell, D. A. (2004). The politics of affective relations. Lanham, ML: Lexington Books.

Chan, J. (2014). Confucian perfectionism: A political philosophy for modern times. Princeton, NJ: Princeton University Press.

Chan, J. (2004). Exploring the nonfailial in Confucian political philosophy. In H. Chaihark, \& D. A. Bell, The politics of affective relations. Lanham, ML: Lexington Books.

Cheng, S.-Y. (1992). The 'c' theory: A chinese philosophical approach to management and decision making. Journal of Chinese Philosophy, 19, 125-153.

Ci, J. (1999). The confucian relational concept of the person and its modern predicament. Kennedy Institute of Ethics Journal, 4, 325-346. 
de Bary, W. T. (1998). Asian values and human rights: A confucian communitarian perspective. Cambridge, MA: Harvard University Press.

Deal, T. E., \& Key, M. K. (1998). Corporate celebration. San Francisco, CA: Berrett-Koehler. Dworkin, R. (1984). Rights as trumps. In J. Waldron, Theories of rights. New York: Oxford University Press.

Edwards, J. R., \& Rothbard, N. P. (2000). Mechanisms linking work and family: Clarifying the relationship between work and family constructs. Academy of Management Review, 25 (1), 178-199.

Eno, R. (1990). The confucian creation of heaven: Philosophy and the defense of ritual mastery. Albany: State University of New York Press.

Fan, R. (2010). Reconstructionist confucianism: Rethinking morality after the west. New York: Springer.

Fan, R.-P. (1999). Confucian bioethics. Dordrecht, Netherlands: Kluwer.

Feinberg, J. (1984). Harm to others. New York: Oxford University Press.

Feinberg, J. (1992). In defense of moral rights. Oxford Journal of Legal Studies, 12, 149-169.

Feinberg, J. (1980). Rights, justice and the bound of liberty. Princeton, NJ: Princeton University Press.

Feinberg, J. (1973). Social philosophy. Englewood Cliffs, NJ: Prentice-Hall.

Feinberg, J. (1970). The nature and value of rights. Journal of Value Inquiry, 4, 243-57.

Fingarette, H. (1972). Confucius: The secular as sacred. Long Grive, IL: Wave Land.

Franceschini, I. (2014). Labour NGOs in China: A real force for political change? The China Quarterly, 218: 474-492.

Gewirth, A. (1996). The community of rights. Chicago: University of Chicago Press. 
Goldman, M. (2005). The struggle for political rights in China. Cambridge: Harvard University Press.

Goldman, M. (2007). Political rights in post-mao china. An Arbor: Association for Asian Studies.

Goodin, R. E. (1995). Political ideals and political relief in nonideal circumstances . British Journal of Political Science, 25 (1), 37-56.

Green, T. H. (1986). Lectures on the principles of political obligation. (P. Harris, \& J. Morrow, Eds.) New York: Cambridge University Press.

Grzywacz, J., \& Marks, N. F. (2000). Reconceptualizing the work-family interface: An ecological perspective on the correlates of positive and nagative spillover between work and family. Journal of Occupational Health Psychology, 5 (1), 111-126.

Hamlin, A., \& Stemplowska, Z. (2012). Theory, ideal theory and the theory of ideals. Political Studies Review , 10, 48-62.

Hardwig, J. (1984). Should women think in terms of rights? Ethics , 94 (3).

Hursthouse, R. (2003). Normative virtue ethics. In S. Darwall, Virtue ethics. Malden, MA: Blackwell Publishing.

Ihara, C. K. (2004). Are individual rights necessary? In K.-L. Shun, \& D. B. Wong (Eds.), Confucian Ethics. New York: Cambridge University Press.

Ilies, R., Wilson, K. S., \& Wagner, D. T. (2009). The spillover of daily job satisfaction onto employees' family lives: The facilitating role of work-family integration. Academy of Management Journal, 52 (1), 87-102.

Ing, M. D. K. (2012). The dysfunction of ritual in early confucianism. New York: Oxford University Press. 
Kinzelbach, K., \& Thelle, H. (2011). Taking human rights to china: An assessment of the eu's approach. The China Quarterly, 205: 60-79.

Kim, S. (2010). Beyond liberal civil society: Confucian familism and relational strangership. Philosophy East and West, 60(4): 476-498.

Kim, T. (2014). Decent termination: A moral case for severance pay. Business Ethics Quarterly, 24(2): 203-227.

Kim, T., \& Strudler, A. (2012). Workplace civility: A confucian approach. Business Ethics Quarterly, $22(3), 557-578$.

Koehn, D. (2001). Confucian trustworthiness and the practice of business in china. Business Ethics Quarterly, 11, 415-429.

Kramer, M., Simmonds, N. E., \& Steiner, H. (2000). A debate over rights: Philosophical enquiries. Oxford, UK: Oxford University Press.

Kupperman, J. J. (2010). Confucian civility. Dao, 9 (1), 11-23.

Lackoff, R. T. (2000). The language war. Berkeley, CA: University of California Press.

Lazare, A. (2004). On apology. New York: Oxford University Press.

Lee, S.-H. (1992). Was there a concept of rights in confucian virtue-based morality? . Journal of Chinese Philosophy, 19, 241-261.

Li, L. (2010). Rights consciousness and rules consciousness in contemporary china. The China Journal, 64: 47-68.

Lin, L.-W. (2010). Corporate social responsibility in china: Window dressing or structural change. Berkeley Journal of International Law, 28 (1), 64-100.

Lindner, E. G. (2001). Humiliation and human rights: Mapping a minefield, Human Rights Review 2(2)" 46-73. 
Luban, D. (2009). Human dignity, humiliation, and torture. Kennedy Institute of Ethics Journal, 19(3): 211-230.

Margalit, A. (1998). The decent society (N. Goldblum, Trans). Cambridge: Harvard University Press.

Muchlinski, P. (2012). Implementing the new un corporate human rights framework: Implications for corporate law, governance, and regulation. Business Ethics Quarterly, 22(1): 145-177.

Nozick, R. (1974). Anarchy, state, and utopia. Basic Books.

O’Brien, K., \& Lianjiang, L. (2006). Rightful resistance in the chinese countryside. New York: Cambridge University Press.

Olberding, A. (2009). Ascending the hall: Style and moral improvement in the analects. Philosophy East \& West, 59 (4), 503-522.

Olberding, A. (2011). Moral exemplars in the analects: The good person is that. New York: Routledge.

Peerenboom, R. (1998). Confucian harmony and freedom of thought. In W. T. de Bary, \& W. Tu, Confucianism and human rights. New York: Columbia University Press.

Peerenboom, R. (1993). What's wrong with chinese rights?: Toward a theory of rights with chinese characteristics . Harvard Human Rights Journal, 6, 29-57.

Perry, J.P. (2007). Studying Chinese politics: Farewell to revolution? The China Journal, 57: 122.

Perry, E. J. (2008). Chinese conceptions of "rights": From mencius to mao and now. Perspectives on Politics, 6(1): 37-50.

Perry, E.J. (2009). A new rights consciousness? Journal of Democracy, 20(3): 17:30. 
Pfeffer, J. (2006). Working alone: What ever happened to the idea of organizations as communities? Stanford Graduate School of Business Working Paper, 1906.

Phillips, M. (1985). Reflections on the transition from ideal to non-ideal theory. Nous, 19 (4), $551-570$.

Popper, K. R. (2002). Conjectures and refutations. New York: Routledge.

Rawls, J. (1971). A theory of justice. Cambridge, MA: Harvard University Press.

Rosemont, J. H. (2008). Responses to contributors. In M. Chandler, \& R. Littlejohn (Eds.), Polishing the chinese mirror: Essays in honor of henry rosemont, Jr. New York: Global Scholoraly Publications.

Rosemont, Jr., H. (1991). Right-bearing individuals and role-bearing persons. In M. I. Bockover, Rules, rituals, and responsibility: Essays dedicated to herbert fingarette. LaSalle , IL: Open Court .

Rosemont, Jr., H. (2004). Whose democracy? Which rights? A confucians critique of modern western liberalism. In K.-1. Shun, \& D. B. Wong, Confucian ethics. New York: Cambridge University Press.

Rosemont, Jr., H. (1988). Why take rights serisouly? A confucian critique. In L. S. Rouner, Human rights and the world's religions. Notre Dame, IN: University of Notre Dame Press.

Sandel, M. (1981). Liberalism and the limits of justice. Cambridge: Cambridge University Press.

Santoro, M. A. (2000). Profits and principles: Global capitalism and human rights in china. Ithaca: Cornell University Press.

Santoro, M. A. (2000). China 2020: How western business can--and should--influence social and political change in the coming decade. Ithaca: Cornell University Press. 
Sarkissian, H. (2010). Minor tweaks, major payoffs: The problems and promise of situationism in moral philosophy. Philosophers' Imprint, 10(9): 1-15

Scheffler, S. (1982). The rejection of consequentialism. Oxford, UK: Oxford University Press.

Schor, J. (1992). The overworked american: The unexpected decline of leisure. New York: Basic Books.

Searle, J. (1962). Meaning and speech acts. The Philosophical Review, 71, 423-32.

Shieh, S. (2009). Beyond corporatism and civil society: The three modes of state-ngo interaction in China. In J. Schwartz, \& S. Shieh (Eds.), State and society responses to social welfare needs in China. London: Routledge: 22-41.

Shun, K.-L. (1993). Jen and li in the analects. Philosophy East \& West, 43, 457-479.

Simmons, A. (2010). Ideal and nonideal theory. Philosophy \& Public Affairs, 38 (1), 5-36.

Smart, J. (1973). An outline of a system of utilitarian ethics. In J. Smart, \& B. Williams, Utilitarianism for and against. New York: Cambridge University Press.

Smith, A. C., \& Stewart, B. (2011). Organizational rituals: Features, functions and mechanisms. International Journal of Management Review, 13 (2), 113-133.

Smith, N. (2008). I was wrong: The meanings of apologies. New York: Cambridge University Press.

Snyder, J. (2010). Exploitation and sweatshop labor: Perspectives and issues. Business Ethics Quarterly, 2(2): 187-213.

Solomon, D., Lo, P.-C., \& Fan, R. (2012). Ritual and the moral life. New York: Springer.

Stemplowska, Z., \& Swift, A. (2012). Ideal and nonideal theory. In D. Estlund, The oxford handbook of political philosophy. New York: Oxford University Press. 
Strudler, A. (2008). Confucian skepticism about workplace rights. Business Ethics Quarterly, 18 (1), 67-83.

Taylor, C. (1985). Philosophy and human sciences. New York: Cambridge University Press.

Thomson, J. J. (1990). The realm of rights. Cambridge, MA: Harvard University Press.

Tiwald, J. (2011a). Confucianism and human rights. In T. Cushman, The routledge handbook of human rights. New York: Routledge.

Tiwald, J. (2011b). Stephen c. angle's sagehood: The contemporary significance of neoconfucian philosophy. Dao, 10:231-235.

Valentini, L. (2012). Ideal vs. non-ideal theory: A conceptual map. Philosophy Compass, 7 (9), 654-664.

van Norden, B. W. (2009). Virtue ethics and consequentialism in early chinese philosophy. New York: Cambridge University Press.

Waldron, J. (Ed.). (1984). Theories of rights. New York: Oxford University Press.

Walker, M. U. (2006). Moral repair: Reconstructing moral relations after wrongdoings. New York: Cambridge University Press.

Wenar, L. (2003). Legal rights and epistemic rights. Analysis, 63, 142-46.

Wenar, L. (2008). The analysis of rights. In M. Kramer, C. Grant, B. Colburn, \& A. Hatzistavrou, The legacy of h.l.a. hart . New York: Oxford University Press.

Wenar, L. (2005). The nature of rights. Philosophy and Public Affairs, 33, 223-53.

Wettstein, F. (2012). CSR and the debate on business and human rights: Bridging the great divide. Business Ethics Quarterly, 22(4): 739-770.

Williams, B. (1981). Moral Luck. Cambridge: Cambridge University Press.

Wong, L. (2011). Chinese migrant workers: Rights attainment, deficits, rights consciousness and personal strategies. The China Quarterly 208: 870-892. 
Wood, S. (2012). The case for leverage-based corporate human rights responsibility. Business Ethics Quarterly, 22(1): 63-98.

Woodruff, P. (2001). Reverence. New York: Oxford University Press.

Zhu, X. (1997). 朱子語類 (Classified conversations of master zhu). Changsha: Yuelu Shushe.

Zhu, X. (1991). Further reflections on things at hand. (A. Wittenborn, Trans.) Lanham: University Press of America. 